Suharsono, Egi Nuryadin. (2019). Pengaruh Suhu Terhadap Siklus hidup Lalat Buah (Drosphila Mel Anogaster). Journal Bioeksperimen. Vol. 5 (2) Pp. 114-120. Doi: 10.23917/bioeksperimen.v5i2.2795

\title{
PENGARUH SUHU TERHADAP SIKLUS HIDUP LALAT BUAH (DROSOPHILA MEL ANOGASTER)
}

\author{
Suharsono*, Egi Nuryadin \\ Jurusan Pendidikan Biologi, Fakultas Keguruan dan Ilmu Pendidikan, Universitas Siliwangi \\ *E-mail: Suharsono225@yahoo.com, egi.nuryadin@unsil.ac.id- \\ Paper diterima : 27 September 2018, Paper publish : September 2019
}

\begin{abstract}
Fruit flies (Drosophila melanogaster) generally have four phases in their life cycle, namely eggs, larvae, pupae and imago. In general, Drosophila melanogaster experiences a life cycle of 8-11 days at optimal temperatures. At lower temperatures the time required to complete its life cycle is relatively longer and slower which is around 18-20 days. Whereas at higher temperatures adult flies that grow will be sterile. The development period of Drosophila melanogaster in its life cycle is influenced by several factors, namely ambient temperature, food availability, level of maintenance density and light intensity. This study aims to determine the effect of temperature on the life cycle of fruit flies (Drosophila melanogaster). The study will be analyzed using quantitative analysis using randomized block design (RBD) with six temperature difference treatments for each treatment and repeated 4 times so that there are 24 experiments. The results showed the development in the Drosophila melanogaster cycle starting from Egg - Larva (Instar I) - Larva (Instar II) - Larva (Instar III) - Pre Pupa - Pupa - Imago. The life cycle of Drosophila melanogaster has an average of 42.08 hours or 1.75 days up to 79.96 hours or 3.33 days in each treatment. And obtained a fast time during the life cycle of Drosophila melanogaster at a temperature of $30^{\circ} \mathrm{C}$ is 10.47 days and the longest at a temperature of $18^{\circ} \mathrm{C}$ is 18.35 days.
\end{abstract}

Keywords: Drosophilla melanogaster, Effect of Temperature, Life Cycle

\section{Pendahuluan}

Lalat buah (Drosophila melanogaster) merupakan organisme yang paling pertama dimanfaatkan oleh manusia untuk mempelajari analisis genetika dan kini termasuk eukariot yang paling dikenal dan digunakan secara luas (Pierce, 2008). Analisis tersebut digunakan untuk memahami transkripsi dan replikasi. Ada seorang ahli yang mempelajari lalat buah bersama dengan murid-muridnya yaitu Thomas. Thomas Hunt Morgan melakukan percobaan terhadap lalat buah di Fly Room Lab, Universitas Kolumbia pada tahun 1910 dan mendapati banyak prinsip hereditas seperti pautan seks, epistasis, multialel dan pemetaan gen (Pierce, 2008).

Drosophila melanogaster banyak digunakan sebagai hewan pada percobaan genetika karena beberapa alasan. Menurut James (2001), lalat buah hanya memerlukan peralatan sederhana dan murah, mudah perawatannya, tidak berbahaya, siklus hidup yang pendek, jantan dan betina mudah dibedakan, imago memiliki kromosom raksasa (polytene) di kelenjar saliva, betinanya mampu menghasilkan 500 telur, memiliki 3 pasang autosom dan sepasang gonosom, dan variasi mutan banyak. Sekuens genom lalat buah telah selesai dan dipublikasikan pada tahun 2000 (Adams, 2000).

Dalam menggunakan organisme sebagai percobaan, siklus hidup merupakan hal yang tak boleh diabaikan. Siklus hidup lalat buat penting untuk dipelajari untuk memudahkan percobaan genetika, pengamatan perkembangan tiap waktu, lalat virgin, reproduksi, breeding, dan karena merupakan hewan model (Nasa, 2006). Menurut Johnstone (1998), pembelajaran siklus hidup organisme bertujuan agar dapat didapatkan informasi prediksi pathogenik, parasit, dan kontrol program. Pada lalat buah siklus hidupnya perlu dipelajari untuk 
memahami life extension, yaitu bagaimana memperpanjang usia hidup bila terjadi mutasi (Carnes, 2015).

Salah satu bahan praktikum pada mata kuliah genetika adalah lalat buah (Drosophila melanogaster), lalat ini banyak kita temukan di alam terutama ditempat buah-buahan yang membusuk. Morfologi lalat buah yang hidup liar pada umumnya berukuran antara 3 sampai dengan $4 \mathrm{~mm}$ dan berwaran kuning kecoklatan. Dalam praktikum selain menggunakan lalat buah yang liar juga menggunakan mutan lalat buah seperti lalat buah mata putih sayap panjang, mata hitam sayap pendek dan eboni. Jenis mutan ini sangat membantu dalam pemahaman pola pola pewariasan sifat. Siklus hidup lalat buah baik yang liar maupun yang mutan mempunyai durasi waktu yang relatip sama, yaitu berkisar antara 8 sampai dengan 20 hari.

Mutan Drosophila melanogaster terjadi karena adanya kesengajaan yang dilakukan dalam penelitian dengan mengubah unsur genetiknya. mutan ini dapat disilangkan dengan sesama mutan maupun dengan lalat buah liar. Pemeliharaan mutan lalat buah ini menjadi penting karena kesalahan pemeliharaan dapat menyababkan kematian atau mungkin mutan menjadi steril. Perkembangan siklus hidup lalat buah ini dibagi menjadi dua periode, periode pertama adalah periode embrionik di dalam telur pada saat fertilisasi hingga penetasan telur menjadi larva muda, sedangkan periode ke dua setelah larva muda menjadi imago dibagi menjadi tiga tahap yaitu larva, pupa dan imago.

Cepat dan lambatnya siklus hidup lalat buah dipengaruhi beberapa faktor diantaranya faktor suhu dan makanan. Suhu yang masih bisa ditoleransi untuk siklus hidup ini berada dikisaran 18 - 30 derajad Celcius. Pada suhu tertentu dari siklus hidup lalat buah bisa menjadi lambat dan pada suhu yang lain siklus hidup bisa dipercepat bahkan pada suhu yang tertentu lalat buah yang dihasilkan bisa menjadi steril.

Medium pemeliharaan stock Drosophilla melanogester yang mula-mula dipergunakan ialah campuran pisang ambon dan tape ketela pohon dengan perbandingan 6:1, medium tersebut dipakai selama lebih dari 15 tahun. Pada tahun 1984 mulai digunakan beberapa medium yang dicobakan untuk memelihara jenis-jenis Drosophilla lainnya dan baru pada lima tahun terakhir digunakan resep yang baru. Hal ini disebabkan oleh kualitas pisang dan tape yang tidak pernah seragam, sehingga dianggap perlu untuk memperoleh medium yang lebih padat dan dapat diandalkan. Resep baru yang dipakai merupakan modifikasi dari resep yang telah ada dan disesuaikan untuk kondisi Indonesia (Marnala, 2010).

Tujuan penelitian ini adalah untuk mengetahui waktu perkembangan yang paling cepat bagi siklus hidup lalat Drosophila melanogaster.

\section{Metode}

Metode penelitian yang digunakan dalam penelitian ini adalah metode eksperimen nyata (True-experimental) dengan menggunakan rancangan acak kelompok (RAK). Perlakuan masing-masing sampel yaitu dengan berbagai macam suhu.

Perlakuan tersebut terdiri dari enam perlakuan yaitu:

1. Perlakuan A dengan menggunakan suhu ruangan (kontrol)

2. Perlakuan $\mathrm{B}$ dengan menggunakan suhu $18^{\circ} \mathrm{C}$

3. Perlakuan $\mathrm{C}$ dengan menggunakan suhu $21^{\circ} \mathrm{C}$

4. Perlakuan D dengan menggunakan suhu $24^{\circ} \mathrm{C}$

5. Perlakuan E dengan menggunakan suhu 27o C dan;

6. Perlakuan $\mathrm{F}$ dengan menggunakan suhu $30^{\circ} \mathrm{C}$

Keenam perlakuan tersebut dilakukan pengulangan empat kali sehingga terdiri dari 24 sampel. Masing-masing perlakuan diamati secara periodik per jam dan diamati 
perubahan morfologi Drosophila melanogaster yaitu mengamati perubahan yang terjadi pada medium, dan mencatat saat terjadinya telur, larva, pupa, dan imago.

Pengumpulan data yang dilakukan dalam penelitian ini dilakukan dengan cara melakukan pengamatan pada setiap perlakuan mulai dari telur, larva, pupa dan imago.

Data yang didapat dari hasil penelitian dianalisis menggunakan analisis kuantitatif menggunakan Rancangan Acak Kelompok (RAK) dengan enam perlakuan yaitu perbedaan suhu pada setiap perlakuan yang diulang sebanyak 4 kali sehingga terdapat 24 percobaan.

\section{Hasil dan Pembahasan}

\section{Hasil yang dicapai}

Proses reproduksi pada Drosophila melanogaster adalah sebagai berikut; Pertama Drosophila jantan menyesuaikan diri dengan menggetarkan sayapnya, kemudian dengan segera posisi kaki jantan berada di bagian perut Drosophila betina dengan posisi rendah untuk menekan dan menjilati kelamin betina. Kemudian Drosophila jantan berkopulasi. Lama waktu Drosophila melakukan fertilisasi sekitar 30 menit, selama jantan mentransfer ratusan sel-sel sperma yang sangat panjang $(1,7 \mathrm{~mm}) \mathrm{ke}$ alat kelamin Drosophila betina.

Metamorfosis pada Drosophila melanogaster termasuk metamorfosis sempurna, yaitu dari Telur - Larva (Instar I) - Larva (Instar II) Larva (Instar III) - Pre Pupa - Pupa - Imago. Perkembangan dimulai segera setelah terjadi fertilisasi, yang terdiri dari dua periode. Pertama, periode embrionik di dalam telur pada saat fertilisasi sampai pada saat larva muda menetas dari telur dan ini terjadi dalam waktu kurang lebih 24 jam. Dan pada saat seperti ini, larva tidak berhenti-berhenti untuk makan (Silvia, 2003)

Berdasarkan data penelitian yang diperoleh bahwa siklus hidup Drosophila melanogaster atau masa perkembangan Drosophila melanogaster sangat singkat yaitu 10,47 hari mulai dari perkembangan telur hingga imago diperoleh waktu yang singkat pada suhu $30^{\circ} \mathrm{C}$. Penelitian ini dimulai dari tanggal 25 Juli 2018 sampai dengan tanggal 12 Agustus 2018. Kegiatan dalam penelitian ini langkah yang pertama dilakukan adalah mempersiapkan media dari buah-buahan yang sudah matang yang di mix dengan bahan yang lainnya seperti agar dan pemanis yang dimasukan kedalam botol untuk memancing Drosophila melanogaster, Setelah Drosophila melanogaster tertangkap dalam botol media yang dibuat selanjutnya memisahkan antara jantan dan betina pada botol yang sudah disediakan.

Setelah itu menyiapkan kembali botol berisi media yang sudah diberi tissue untuk tempat bertelur Drosophila melanogaster dan dimasukkan beberapa jantan dan betina supaya dapat melaksanakan perkawinan dan menghasilkan telur. Kurang lebih satu hari Drosophila melanogaster jantan dan betina dipelihara sampai menghasilkan telur, dan

Drosophila melanogaster ini dilepaskan kembali ke habitat aslinya. Selanjutnya telur disimpan pada botol media yang sudah disiapkan dan dimasukkan kedalam alat penelitian yang sudah dibuat seperti (Gambar 1) berikut, lalu diamati perubahan-perubahan yang terjadi selama siklus berlangsung. 

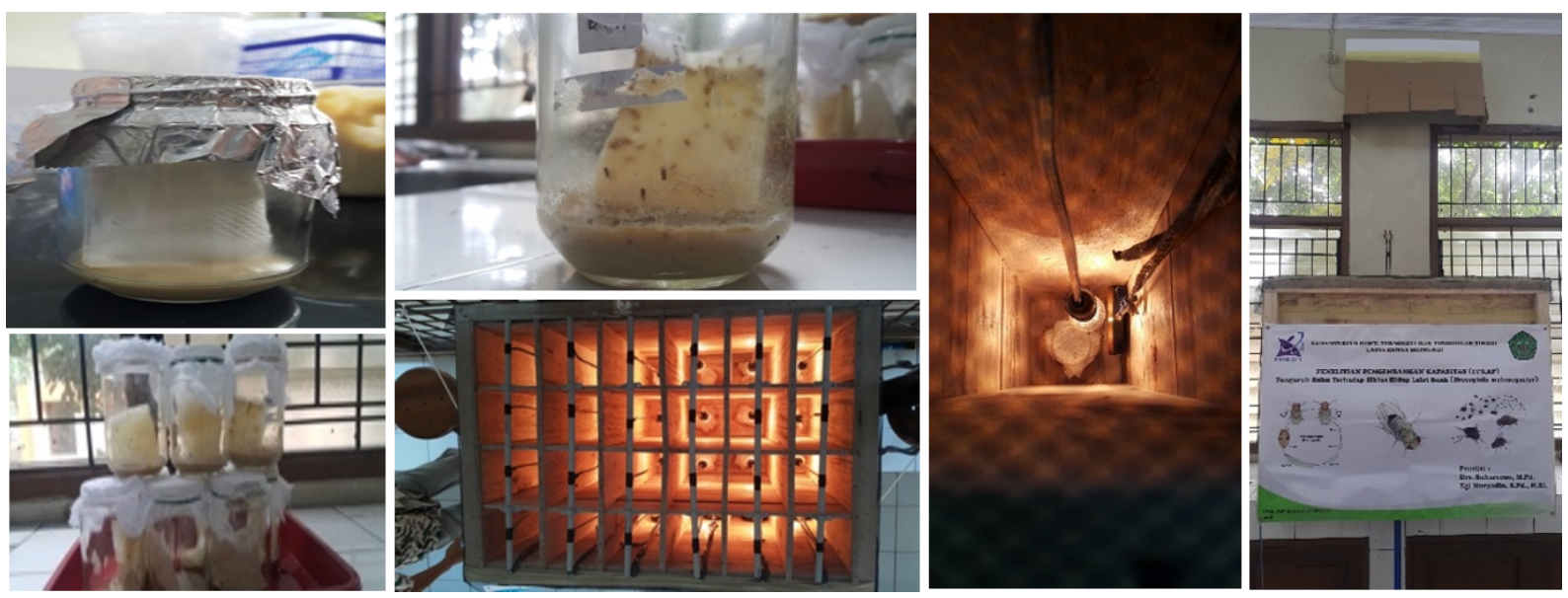

Gambar 1. Perlakuan yang dilakukan untuk melihat perkembangan (siklus hidup) lalat Drosophila melanogaster

Telur Drosophila melanogaster ini seperti titik berwarna putih, pada hari pertama semua botol sampel terdapat telur Drosophila melanogaster yang menempel

Telur Drosophila melanogaster ini seperti titik berwarna putih, pada hari pertama semua botol sampel terdapat telur Drosophila melanogaster yang menempel pada tissue di media. Telur ini menetas menjadi larva instar I selama kurang lebih 1-2 hari. Perubahan yang paling cepat telur menetas menjadi larva (instar I) yaitu perlakuan dengan suhu $30^{\circ} \mathrm{C}$ dengan waktu 20 jam atau 0,83 hari. Tidak semua botol sudah menjadi larva dalam waktu yang sama, yang paling lama pada suhu $18^{\circ} \mathrm{C}$ dengan waktu 38,75 jam atau 1,61 hari.

Telur Drosophila melanogaster dilapisi oleh dua lapisan, yaitu satu selaput vitellin tipis yang mengelilingi sitoplasma dan suatu selaput tipis tapi kuat (Khorion) di bagian luar dan di anteriornya terdapat dua tangkai tipis. Korion mempunyai kulit bagian luar yang keras dari telur tersebut (Borror, 1992). Larva Drosophila berwarna putih, bersegmen, berbentuk seperti cacing, dan menggali dengan mulut berwarna hitam di dekat kepala.

Untuk pernafasan pada trakea, terdapat sepasang spirakel yang keduanya berada pada ujung anterior dan posterior (Silvia, 2003). Larva instar I ini berwarna putih, bersegmen, berbentuk seperti cacing, dan motil, usia larva instar I ini sampai berubah ke larva instar 2 yaitu sekitar 1-4 hari.
Hasil yang diperoleh pada suhu $30^{\circ} \mathrm{C}$ perkembangan yang paling cepat larva (instar I) menjadi larva (instar II) yaitu 65,50 jam atau 2,70 hari dan yang paling lama pada suhu $18^{\circ} \mathrm{C}$ yaitu 98 jam atau 4,08 hari. Kemudian dari larva (instar 1) ini berubah manjadi larva (instar 2) dimana ukuran larva ini lebih besar dibanding larva (instar I), terlihat adanya warna kehitaman pada bagian anterior larva (mulut larva), dan mampu menggali dengan mulut tersebut. Perubahan dari larva (instar 2) menjadi larva (instar 3) dimana mulut hitam terlihat jelas berbentuk sungut, bergerak lebih aktif, ukuran menjadi lebih besar, lamanya fase ini sekitar 1-3 hari. Hasil penelitian yang paling cepat diperoleh pada suhu $30^{\circ} \mathrm{C}$ yaitu 43 jam atau 1,79 hari dan yang paling lama pada suhu $18^{\circ} \mathrm{C}$ dengan waktu 89,25 atau 3,71 hari.

Kemudian dari larva Drosophila melanogaster ini memasuki fase awal pembentukan pupa (prepupa), diperoleh pada suhu $30^{\circ} \mathrm{C}$ yang paling cepat 40,25 jam atau 1,67 hari. Dalam fase ini tidak ada pergerakan, muncul selaput yang mengelilingi larva, tubuhnya memendek. Perkembangan pre pupa menjadi pupa diperoleh suhu $30^{\circ} \mathrm{C}$ dengan waktu 40,00 jam atau 1,66 hari. setelah 1-3 hari sudah terlihat adanya pupa dimana kutikula menjadi keras dan berpigmen, tidak bergerak (diam). Dan setelah 1-3 hari maka keluarlah imago dimana terlihat Drosophila melanogaster yang sudah bisa bergerak, warna masih agak pucat dan sayap belum mengembang/terbentang. 
Saat kutikula tidak lunak lagi, larva muda secara periodik berganti kulit untuk mencapai ukuran dewasa. Kutikula lama dibuang dan integumen baru diperluas dengan kecepatan makan yang tinggi. Selama periode pergantian kulit, larva disebut instar. Instar pertama adalah larva sesudah menetas sampai pergantian kulit pertama. Dan indikasi instar adalah ukuran larva dan jumlah gigi pada mulut hitamnya. Sesudah pergantian kulit yang kedua, larva (instar ketiga) makan hingga siap untuk membentuk pupa.
Pada tahap terakhir, larva instar ketiga merayap ke atas permukaan medium makanan ke tempat yang kering dan berhenti bergerak. Dan jika dapat diringkas, pada Drosophila, destruksi sel-sel larva terjadi pada prose pergantian kulit (molting) yang berlangsung empat kali dengan tiga stadium instar : dari larva instar 1 ke instar II, dari larva instar II ke instar III, dari instar III ke pupa, dan dari pupa ke imago (Ashburner, 1985).

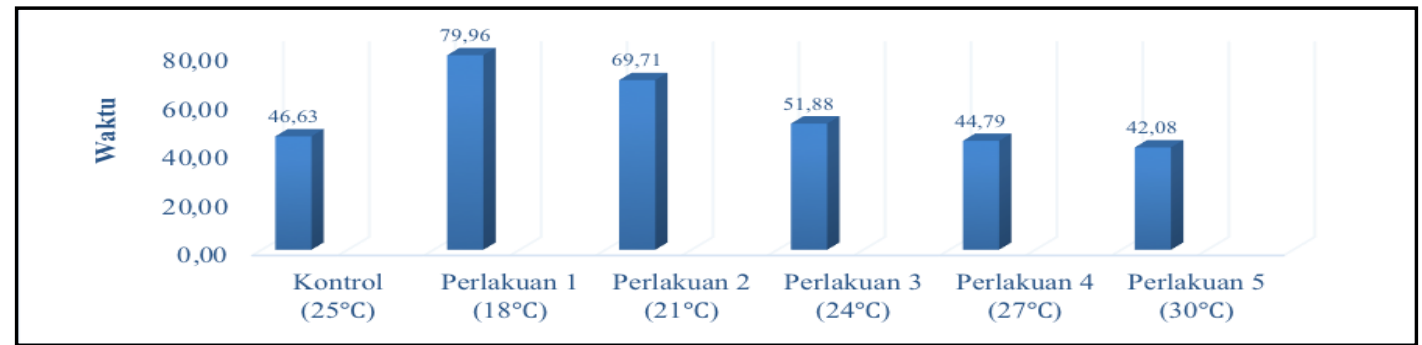

Gambar 2. Rata-rata Waktu dan Ulangan Pada Setiap Fase Siklus Hidup Lalat Buah (Drosophila melanogaster)

Selama makan, larva membuat saluransaluran di dalam medium, dan jika terdapat banyak saluran maka pertumbuhan biakan dapat dikatakan berlangsung baik. Larva yang dewasa biasanya merayap naik pada dinding botol atau pada kertas tissue dalam botol. Dan disini larva akan melekatkan diri pada tempat kering dengan cairan seperti lem yang dihasilkan oleh kelenjar ludah dan kemudian membentuk pupa.

Saat larva Drosophila membentuk cangkang pupa, tubuhnya memendek, kutikula menjadi keras dan berpigmen, tanpa kepala dan sayap disebut larva instar 4. Formasi pupa ditandai dengan pembentukan kepala, bantalan sayap, dan kaki. Puparium (bentuk terluar pupa) menggunakan kutikula pada instar ketiga. Pada stadium pupa ini, larva dalam keadaan tidak aktif, dan dalam keadaan ini, larva berganti menjadi lalat dewasa (Ashburner, 1985)Struktur dewasa tampak jelas selama periode pupa pada bagian kecil jaringan dorman yang sama seperti pada tahap embrio. Pembatasan jaringan preadult (sebelum dewasa) disebut anlagen. Fungsi utama dari pupa adalah untuk perkembangan luar dari anlagen ke bentuk dewasa (Silvia, 2003)
Secara keseluruhan, dapat terlihat bahwa siklus hidup Drosophila melanogaster ini dimulai dari Telur - Larva (Instar I) - Larva (Instar II) - Larva (Instar III) - Pre Pupa - Pupa - Imago.

Siklus hidup Drosophila melanogaster tersebut berkisar rata-rata paling cepat pada perlakuan 1 dengan suhu $30^{\circ} \mathrm{C}$ selama 42,08 jam atau 1,75 hari, perlakuan 2 dengan suhu $27^{\circ} \mathrm{C}$ selama 44,79 jam atau 1,86 hari, kontrol dengan suhu $25^{\circ} \mathrm{C}$ selama 46,63 jam atau 1,94 hari, perlakuan 3 dengan suhu $24^{\circ} \mathrm{C}$ selama 51,88 jam atau 2,16 hari, perlakuan 2 dengan suhu $21^{\circ} \mathrm{C}$ selama 69,71 atau 2,90 hari dan yang paling lama perlakuan 1 dengan suhu $18^{\circ} \mathrm{C}$ selama 79,96 jam atau 3,33 hari seperti pada Gambar 2. Waktu yang paling cepat selama siklus hidup Drosophila melanogaster yaitu pada suhu $30^{\circ} \mathrm{C}$ yaitu 10,47 hari dan yang paling lama pada suhu $18^{\circ} \mathrm{C}$ yaitu 18,35 hari.

Metamorfosis lalat buah tergantung pada faktor lingkungan seperti suhu, kelembaban dan faktor makanan sangat berpengaruh terhadap populasi serangga. Berdasarkan hasil penelitian waktu yang diperlukan dalam metamorphosis lalat buah dari periode ke periode tidak sama antara Telur - Larva (Instar I) - Larva (Instar II) - Larva (Instar III) - Pre Pupa - Pupa - Imago. 
Penelitian yang diperoleh diperoleh yaitu waktu yang cepat selama siklus hidup Drosophila melanogaster pada suhu $30^{\circ} \mathrm{C}$ yaitu 10,47 hari dan yang paling lama pada suhu $18^{\circ} \mathrm{C}$ yaitu 18,35 hari sesuai dengan yang dikemukakan oleh malini dan rasmi (1993) bahwa lalat yang dipelihara pada suhu rendah mempunyai kemampuan reproduksi lebih rendah apabila dibandingkan dengan lalat yang dipelihara pada suhu tinggi. Menurut siwi (2005) Drosophila melanogaster betina yang banyak mendapatkan sinar akan lebih cepat menghasilkan telur. Shorrocks (1972) suhu optimal untuk pertumbuhan Drosophila melanogaster sekitar $25-28^{\circ} \mathrm{C}$. Pribadi dan Anggraeni (2010) Suhu lingkungan berpengaruh terhadap metabolisme tubuh serangga dengan mengaktifkan enzimenzim pencernaan.

Aktifitas enzim-enzim pada serangga akan meningkat seiiring kenaikan suhu sehingga intensitas makan akan meningkat dan akan berpengaruh pada perkembangan serangga. Wonderly (2002) Suhu berpengaruh terhadap siklus hidup Drosophila melanogaster.

\section{Simpulan}

Selama siklus hidup Drosophila melanogaster didapatkan waktu yang paling cepat 10,47 hari pada suhu $30^{\circ} \mathrm{C}$. Siklus hidup Drosophila melanogaster ini dimulai dari fase perkembangan Telur - Larva (Instar I) - Larva (Instar II) - Larva (Instar III) - Pre Pupa - Pupa - Imago. Dan diperoleh waktu yang paling lama yaitu 18,35 hari pada suhu $18^{\circ} \mathrm{C}$. Rata-rata perlakuan suhu pada perkembangan setiap fase siklus hidup Drosophila melanogaster ini yaitu 42,08 jam atau 1,75 hari sampai dengan 79,96 jam atau 3,33 hari pada masing-masing perlakuan.

\section{Daftar Pustaka}

Adams, M.D. 2000. The genome sequence of Drosophila melanogaster. Science. doi:10.1126/ science.287.5461.2185. PMID 10731132.

Ashburner, Michael. 1989. Drosophila, A Laboratory Handbook. Coldspring Harbor Laboratory Press. USA.

Borror, D. J., Charles, A. T., \& Norman, F. J., 1992. Pengenalan Pelajaran Serangga. Yogyakarta: Gajah Mada University Press

Carnes, M.U. 2015. The genomic basis of postponed senescence in Drosophila melanogaster. PLOS ONE. 10 (9): e0138569. doi:10.1371/journal.pone.0138569.

Hernawan, Edi. (2008). Penghantar Statistika. Universitas Siliwangi, Tasikmalaya, Tidak diterbitkan.

James, H.S. 2001. Drosophila melanogaster: The Fruit Fly. USA: Fitzroy Dearborn Publishers.

Johnstone, C. 1998. Importance of life cycles - epidemiology. http://cal.vet.upenn.edu/projects/ merial/introduction/intro_5.htm. Diakses 22 September 2016.

Malini, D., dan Rasmi, D. 1993. Perbandingan Kemampuan Reproduksi lalat Buah (Drosophila annasse) yang Dipelihara pada Suhu Lingkungan yang Berbeda. Bali: Universitas Udayana.

Marnala. 2010. Siklus hidup lalat buah. Tersedia: [http://www.marnala.co.cc/2010/07/Teknik Dasar Genetika.html.] diakses tanggal 22 Januari 2018 pukul 22.30 WIB.

Mustamin, K. 2009. Buku Dasar Genetika. Fakultas Sains dan Teknologi UIN Alaudin Makassar: Makassar.

Nasa. 2006. Flies in space - Drosophila: Life cycle. http://quest.nasa.gov/projects/flies/lifeCycle.html. Diakses 22 September 2016.

Pierce, B.A. 2008. Genetics: A conceptualapproach. 2nd edn. New York: Freeman, W. H. \& Company. 
Purwoto dan Wiryosoewarto. 1994. Genetika dan Evolusi Cetakan I. Depdikbud: Jakarta.

Shorrock. 1972. Drosophila. London: Gin and Company Limited.

Silvia, T. 2003. Pengaruh Pemberian Berbagai Konsentrasi Formaldehida Terhadap Perkembangan Larva Drosophila. Bandung: Jurusan Biologi Universitas Padjadjaran.

Suryo. 1997. Genetika Strata 1. Yogyakarta: Gadjah Mada University Press

Suryo. 2010. Genetika Untuk Strata 1. Yogyakarta: Gadjah Mada University Press

Wonderly, B.A. 2002. Drosophila Genetics Lab 1 (serial on line). www.accesexcellence.org/atg/data/ released/0083_BettyAnnWonderly?Lab1.html 